\section{Cold War against the Vatican?}

SIR - Is Nature waging war on the Vatican? It would seem so, at least judging from a recent leading article ${ }^{1}$ and an even more recent Commentary by John Godfrey, "The Pope and the ontogeny of persons"2. A reply by Helen Watt ${ }^{3}$ to this Commentary has already exposed some of its scientific weakness and misinterpretations. The Pope has correctly interpreted the facts of human reproduction and development in his statement that ". . .we should envisage human persons coming into being .... as each bright day is imperceptibly created during dawn"2.

We do not intend to argue on single scientific points, but to denounce Godfrey's falsification of data. To start with, he says that "[i]n his recent book Crossing the Threshold of Hope, Pope John Paul II airs his view on human reproduction". In fact the Pope discusses neither the biological nor the philosophical/theological aspects of human reproduction. He deals only with the abortion issue, from a social and moral standpoint, very briefly in one of the last chapters ${ }^{4}$. Again, Godfrey sounds persuasive in stating that "[u]ntil the late nineteenth century Christian tradition, following Aquinas, tended to grade the protection to the incipient person according to the stages of development". We would be curious to know which documents of the Christian tradition led Godfrey to this conclusion. Again, the truth is that from the very beginning of the Christian tradition the Fathers and Doctors of the Church, notably Didakè, Athenagoras, Tertullian and others, all the way to Pius IX, unanimously spoke against abortion at any stage of pregnancy. Even those who followed the opinion of delayed animation considered the act of abortion, if not a homicide, gravely immoral. Aquinas himself, despite his views on ensoulment, clearly dictated in those days by a virtually complete ignorance of the biology of human reproduction, condemned abortion from the moment of conception. Aquinas is also misinterpreted on his views about the concept of Epikeia, according to which there are exceptional situations when the law can be infringed for a good cause. But Epikeia refers to positive law, not to natural law.

Finally, Godfrey hints at the Pope's ignorance of modern genetics and embryology. Given that the Pope is not a scientist, as he himself admits ${ }^{2}$, Godfrey must mean either that the Pope's scientific advisers are ignorant, or that he chooses

\footnotetext{
. Nature 371, 185 (1995)

2. Godfrey, J. Nature 373, 100 (1995)

3. Watt, H. Nature 373,379 (1995)

John Paul II Crossing the Threshold of Hope (Jonathan Cape, 1994).

5. Report of the Committee of Inquiry into

Fertilization and Embryology (HMSO, London,
}

to ignore their advice. Godfrey will probably be surprised to know that possibly the clearest reflection of the Pope's view on the biology of human reproduction is contained in chapter 11, p. 65 of the Warnock Report $\mathrm{s}^{5}$.

\section{Angelo Serra}

\section{Giovanni Neri}

Istituto di Genetica Medica,

Università Cattolica,

Facoltà di Medicina "A. Gemelli",

Roma, Italy

SIR - I congratulate Godfrey ${ }^{1}$ 'on having understood in part the doctrine of the Roman Catholic Church. As he says, "the concept of 'person' is not only a marvellous theory; it is at the centre of the human ethos" (John Paul II: Crossing the Threshold of Hope). The origin of the human being is fertilization, the onset of the diploid phase. Haploid gametes (ovule and sperm) have never been considered men or women, persons or individuals having any rights.

Godfrey is right to say that fertilization is a long, complex process and that ontogeny is gradual. Rightly, there is no biological discontinuity that indicates when the soul is infused, but this is the main reason to protect the life of the fertilized egg: it may already be a human person and nobody can demonstrate the contrary. "In dubio, pro reo." If someone does not respect human life from its very beginning and practises abortion, she or he is committing murder.

This is why Jesus Christ and His Church, the Roman Catholic, have defended human life from conception, that is to say, from fertilization, not from implantation or any later event.

\section{J. A. Manzanera}

Universidad Politécnica de Madrid, UDAnatomia, Fisologiay Genetica, 28040 Madrid, Spain

SIR - We can all appreciate Godfrey's efforts $^{1}$ to educate us in reference to contemporary thinking in the area of human embryology developments, but he, as others of similar mind, will have to continue to be disappointed if he expects to document a physiochemical event that announces the infusion of a soul into the human embryo. He presents interesting and well-known information regarding the cellular gradualism that characterizes mammalian fertilization, but this is hardly an appropriate argument that the 'humanization' of the embryo must also proceed as a continuum. One cannot expect the infusion of the human soul at conception to be a process that would lend itself to any form of measurement or physical documentation.

It is fascinating that Godfrey would resurrect not only the philosophical but also the biological beliefs of St Thomas Aquinas and Aristotle to reinforce his own scientific/religious concepts. $\mathrm{He}$ further introduces the popular concept that the evolving organism can become human only within the framework of the developing central nervous system. Godfrey implicates myelinization. Others have even employed the appearance of the primitive streak, an early phenomenon in central nervous system differentiation, to imply neurocellular uniqueness in the embryo.

Even the US National Institutes of Health Panel on Human Embryo Experimentation was willing to grant the embryo at all stages a uniqueness that sets it above other cellular systems. Yes, each human zygote in its own intrinsic biological form is constantly undergoing vigorous alteration and change based from the very beginning on its own genetic blueprint. In time, this self-contained molecular template can direct the evolving structure into becoming a completely formed and functioning human being.

Each of us is formed in the image and likeness of God. As a consequence, there will never be any scientific evidence that the human embryo at any stage of its development will demonstrate ensoulment.

Robert J. White

Case Western Reserve University,

MetroHealth Medical Center,

2500 MetroHealth Drive,

Cleveland, Ohio 44109-1998,USA

SIR - I am scared, thinking about the implications of Godfrey's declaration that "there is no moment when human life starts". If that is true, then personal (individual) responsibility loses its meaning, as we really do not know (or don't care) when this or that person started to exist. What would be the point in celebrating birthdays, for example? Does this mean that the whole of living humanity is just one living mass not unlike a bacterial colony or a tree (and not comprised of individual persons)? Without this respect for individual persons, I can see how Hitler could have easily used this declaration as a scientific justification for the Holocaust - he perceived the Jews as a corruption to the pure race, and disposed of them, much like a tree would shed leaves that have dried up.

\section{Carlo A. Arcilla}

University of Illinois,

Department of Geological

Sciences (M/C 186)

845 West Taylor Street, $R m 2438$,

Chicago, Illinois 60607-7059, USA

Letters submitted for Correspondence should be typed, double-spaced, on one side of the paper only. 